\title{
Government Expenditure, Savings, FDI and Economic Growth: An Impact Analysis
}

\author{
Felicia Abada ${ }^{1}$, Charles Manasseh ${ }^{2, *}$ \\ ${ }^{1}$ Social Sciences Unit, School of General Studies, University of Nigeria, Nsukka, Nigeria \\ ${ }^{2}$ Department of Banking \& Finance, University of Nigeria, Enugu Campus, Enugu, Nigeria
}

Email address:

charssille@gmail.com (C. Manasseh)

${ }^{*}$ Corresponding author

\section{To cite this article:}

Felicia Abada, Charles Manasseh. Government Expenditure, Savings, FDI and Economic Growth: An Impact Analysis. Journal of Investment and Management. Vol. 9, No. 4, 2020, pp. 92-99. doi: 10.11648/j.jim.20200904.11

Received: June 28, 2020; Accepted: July 8, 2020; Published: December 31, 2020

\begin{abstract}
This study investigates the impact of government expenditure, savings, FDI on economic growth in Nigeria for 1995 to 2018. The data for the study was sourced from World Bank's World Development Indicator, while OLS estimating technique was employed for the analysis. Using OLS estimator, the empirical evidence from the findings show that government expenditure, savings, FDI significantly impacted economic growth. Therefore, government expenditure, savings, foreign direct investments are key determinants of economic growth in Nigeria. Based on the findings, we suggest that the Nigerian government should reduce the personal income tax so as to promote the disposal income and invariables savings. Also, effort should be made to promote stable and less volatile macroeconomic environment for the attraction of foreign direct investment inflow into Nigeria. This in turn could boost employment and increase in income and the individual savings. Further, we found government expenditure to negatively relate to economic growth. Hence, government spending in itself is not bad but should be utililize efficiently to help drive economic growth. Hence, we suggest that government spending should be reduced since it does not contribute immensely to the growth of the economy.
\end{abstract}

Keywords: Government Expenditure, Savings, FDI and Economic Growth

\section{Introduction}

Government spending constitutes the key components in public finance which is vital to economic growth and development. Over the years, fiscal operations have revealed a continuous increase in government expenditure to promote economic performance $[30,18,19]$. Hence, properly adjusted government expenditures do not only guarantee economic stability, but also create room for infrastructural development. Hence, Keynesargued that government expenditures promote increase in aggregate demand, increase in national income and economic growth through its multiplier effects in areas such as healthcare, education and agriculture sector among others. Thus, growth in these sectors promotes economic growth, and enhances productivity through the attraction of the needed foreign direct investment with enhance job creation and improved per-capita income [34]. Consequently, improvement in per-capita income may promote disposable income of the people and their savings. Thus, theconcept of saving simply means deferred consumption, and it has increasingly gain greater attention in fiscal policies in recent times. Irrespectively of the fact that savings has been argued to be vital in promoting economic growth, its contractionary or expansionary effect proposed by Keynesian should be treated with care because of it side effect [32].

There are increasing controversies in macroeconomics bothering onrelationships between savings and economic growth. This arises out of different propositions and mixed findings among various literatures [52, 13]. Hence, the neoclassical schools believe that higher savings lead to higher economic growth. Moreso, increase in saving stimulates economic growth through investment [40]. According to Ricardo-Barro effect, also known as Ricardian equivalence, main agent of economic activity leads to accumulation of capital, and when channeled into production process, prevents the marginal productivity of private capital from falling. However, if government spending increases 
private productivity, it ultimately leads to economic growth. But, before government expenditure reaches a steady state, it has a positive and maximized impact on growth. Succinctly, the nexus between economic growth and FDI in any economy largely depends on the level of coordination and management of investment strategies [52], and there cannot be any meaningful investment without saving, because low saving rates accounts for major growth inhibiting factors particularly, in developing countries [22]. Therefore, Foreign Direct Investment (FDI) serves as principal tools for enhancing economic growth. But sometimes the inflows are affected by the size of government expenditures instead of private investment. Hence, government spending constitutes the major element in governance.

Consequently, as there is hardly self-sufficiency, both developed and developing nations have continually yearn for foreign direct investment (FDI) due to the inherent benefit to stare economic growth. Hence, many countries in Africa has been seeking for FDI as evidenced by the New Partnership for Africa's Development (NEPAD), structured to attract foreign investment to Africa as a major component of its operation [4]. However, the benefits of this initiative is in short supply in Africa, due to political instability, corruption, poor infrastructure, acute shortage of foreign exchange and unfriendly macroeconomic policy pronouncements, amongst others. FDI instrument is an effective composite bundle of capital stock and technology that can boast economic growth directly or indirectly through channels and spillovers effect $[6,20]$. It is therefore a potent force for growth whichhas taken root among development economists [3, 35, 16, 46, 44, $21,7,12,15]$. However, the question of how to deploy government spending, attract meaningful FDI inflow, and promote savings to appropriately respond to questions of growth in an economy, has been a challenging in contemporary times. Regrettable, despite the rising profile of spending by governments across times, and policy mix initiated to encourage FDI inflow and to promote savings, developing countries have been bedeviled by successive years of dilapidated infrastructural facilities, occasioned by poor policy pronouncement [31, 37, 50, 34, 29]. Accordingly, understanding the impact of government spending, savings, foreign direct investment inflow on economic growth is crucial for informed economic decisions.

\section{Review of Related Literatures}

There are extant studies on the concepts of economic growth in economics and allied literatures. However, these studies over time have assumed controversial dimensions on what hitherto, constitutes the indices of economic growth. Hence, economic growth is determined by diverse indicators but with different frameworks [37, 17, 5]. For instance, [37] noted a two way directional effects between economic growth and government expenditure on administration, as well as economic growth and government expenditure on economic services. However, government spending are often made to fulfill the developmental objectives of the state, and expenditures on administration and economic services falls on the same realm. [36, 51] affirmed that government spending on various aspect of economic chain is geared towardsthe growth of the economy. Following the HarrodDomar economic growth model, [27] noted that savings has positive and expansionary effect on economic growth. Essentially, savings are primarily affected by multiplicity factors, such as low wage, inflation, high interest rate and lack of government incentives etc. But the continuous depletion of exchange rate within a system most times elicits positive impact on savings, because it leads to enhancement of terms of trade with additional attraction of foreign direct investment through smart policy arrangements [25, 24]. Proponents of economic growth had underscored the role of savings as a veritable means for surplus accumulation and growth, and the Keynesian's aggregate demand-based theory of economy also hinged on aggregate expenditure, which has a direct bearing to savings for economic growth [25].

In critical examination of the indicators, studies of $[8,11$, 1] produced a mixed outcome that stressed the significant effect of efficacy government spending to engineer economic growth. According to them, they affirm its potency to turn negative or null in some cases, especially, if the drivers such as efficient market and size, economic independence and availability of reasonable technology are in short supply. However, in neoclassical theory, economic growth is brought about by the combination of qualities and other ancillary factors of production, efficient allocation of government spending on key macroeconomic indicators that drives the economy. The whole question of economic growth typically refers to the growth potential output - production at full employment which is caused by growth in aggregate demand within an economic system [8]. According to [42], the misconception about government expenditures to grow the economy is crystallized on Wagner's work, where he asserted that long-run situations exist in public expenditure to grow relatively to the growth of the economy, and that, as the economy develops over time, the activities and functions of the government would increase. This propositions sharply engendered division amongst scholars, for instance, $[9,38$, $48,49]$ argued against it. However, exploring the resilience of government expenditure by examining the rationale subsumed in economic growth and development theory, the joint views of the aforementioned scholars are all paramount to subject under study. There has been increasing argument that healthy macroeconomic indicators contribute to greater foreign direct investment inflows. This is because; other key aspects of governance such as policy formulations and implementation, institutions quality control and economic liberalization also play a central role in attracting FDI [34]. Contrarily, [4] argues that foreign direct investment leads to parasitic relationship and retards real development in domestic economy thereby impeding economic growth.

In furtherance to ascertain the impact of government spending onvariables of economic growth employing disaggregated data approach, $[26,10]$ noted a negative as well as positive relationship between government 
expenditure and economic growth in short and long run in developing nations. These variables include but limited to the quantum of Investment, savings, foreign direct investment and government consumption with openness to trade related pronouncements. There could also be negative long-run effect of government spending economic growth [39]. This is because, increases in government debt exert significant effect on economic growth, and as the government debt profile rises the effect on economic growth diminishes rapidly and the growth impacts become negative. Similarly, a panel examination was conducted on effectuality of variables of economic growth in selected countries [30]. They applied the model estimation and noted a non-linear relationship between the variables, and further submitted that there is a negative relationship in government expenditure and economic growth, which means that unguided consumptions and spending of public funds could diminish the capacity for productive investment thereby impeding growth. This result validates the outcome of an earlier study by [23], although he had posted that a level of economic development plays a vital role in the interaction between growth and government spending.

Furthermore, the intervention strategies of governments in terms public spending, savings and the attraction of foreign direct investment are rationales to stimulate market economy and enhance steady economic growth. However, as crucial as the aforementioned macroeconomic variables and the insecure economic environment, characterized by low spending and savings, erosion of investors' confidence will adversely affect economic growthand stability, because it is through public expenditure that the state attempts to win support from the people and therefore perpetuates its economic ideology. Hence, [51, 37, 28] empirically investigated the significance of government spending on crucial sectors on economic growth. This was to ascertain the extent to which the spending has responded to its main objectives. Employing Johansen Co integration test, andARDL, the study noted a two sided effects of economic growth. In like manner, [5] empiricallyexamined Wagners's proposition adopting the ARDL Model. He also noted that long-run co integration existed between economic growth and government expenditure, but evidence for Wagner's law was absent. On the other hand, [42] examinedwhether government expenditure has engendered growth in the economy through capital and recurrent expenditures, which were regressed against the gross domestic product. Analyzing documentary data generated over time, he submitted that the series were co-integrated in the long run using Johansen cointegration. The study further argued that recurrent expenditure impacts positively on gross domestic product (GDP), while the influence of capital expenditure on GDP turned out negative. In addition, [41] study revealed a oneway casual relationship between gross domestic savings and gross domestic product in both developed and developing countries. However, it also confirmed the absence of causal relationship between gross domestic product and gross domestic savings in the two different economies. Hence, The work of [41] established the links between savings and economic growth using ordinary least squares method (OLS). They also maintained that the more the domestic savings rate, the better the economic growth rate. This proposition ultimately affirms how significantly savings could impact on investment which invariably translates to economic growth. In addition, investigating the hypothesized prediction using panel and classical pooled regression model, [32, 33, 47, 43] argued that domestic saving rate has exerted a statistically significant effect on growth rate of GDP over time with high propensity of adverse effects in precarious times.

In addition, scholar such as [8] and [14] examined the impact of foreign direct investment on economic growth using Autoregressive Lag Distribution approach to establish the existing short and long-term relationship between foreign direct investment and economic growth. The result explained that foreign direct investment has significant impact on economic growth in both short and the long term in the economies under study. It also asserts that other determinants of economic growth shows that domestic investment and human capital leads to a positive and significant effects in the short run rather than in the long run, while the observable degree of trade openness has a negative effect on short-term and long-term economic growth. Other studies like [2] studied the impact of foreign direct investment and economic growth in developing countries. These studies argued that foreign direct investment inflow affects most factors in the economy, which in turn affect economic growth. I like manner, [27] studied the relationship between foreign direct investment and economic growth in Nigeria. The study revealed that FDI has a positive but has insignificant impact on economic growth for the period under study. Furthermore, findings also supported Harrod-Domar growth model which postulates that saving rate positively or directly related to GDP in her study on savings and economic growth.

\section{Methodology, Data and Source}

In order to establish the impact of government expenditure, savings, foreign direct investment on economic growth, we employed ordinary least squares (OLS) estimation technique adopted by [26]. In furtherance, we also employed the real gross domestic product (RGDP) to measure the economic growth, government expenditure (GEXP), savings (SAV), foreign direct investment (FDI), investment (INV) a proxy of gross fixed capital formation, real interest rate (RINT), and real exchange rate (REXR). Time series annual data for 1995 to 2018 is used. The scope of the study was based on the availability of data. Thus the data was sourced from World Bank's World development indicators (WDI) 2019 edition. Real Gross Domestic Product (GDP) is an inflation-adjusted measure that reflects the value of all goods and services produced by an economy in a given year (expressed in base-year prices) and is often referred to as "constant-price," "inflation-corrected", or "constant dollar" GDP. Investment (INV) is the value of fixed capital assets (plus stocks) produced in an economy over a period of time. 
It also referred to as amount of goods purchased or accumulated per unit time which are not consumed at the present time. Real interest rate (RINT) is the rate of interest an investor, saver or lender receives (or expects to receive) after allowing for inflation. Real exchange rate (REXR) is the weighted average of a country's currency in relation to an index or basket of other major currencies. The weights are determined by comparing the relative trade balance of a country's currency against each country within the index. Government Expenditure (GEXP) measures the money spent by the public sector on the acquisition of goods and provision of services such as education, healthcare, social protection, and defense. In addition, Savings (SAV) is to aggregate of public and private savings held within the economy. Foreign direct investment (FDI) is a measure of investment made by a firm or individual in one country into business interests located in another country.

Ordinary least squares (OLS) techniques was adopted and the choice for this technique was due to its special characteristics it possess such as (a) OLS model produce residuals that have a mean of zero, have a constant variance, and are not correlated with themselves or other variables. (b) It produces estimates that have best linear unbiased (BLUE) property. (c) As the sample size increases to infinity, the coefficient estimates converge on the actual population parameters when compared to other estimation methods. However, ordinary least squares model is built on the assumptions which states that the regression model is linear in parameters; explanatory variable is assumed to be nonstochastic; there is zero men value of disturbance $\left(\mu_{\mathrm{i}}\right)$; there is homoscedasticity or equal mean or the conditional variances of $\mu_{\mathrm{i}}$ are identical; there is no autocorrelation between the disturbances; there is zero covariance between $\mu_{\mathrm{i}}$ and explanatory variables; the number of observation $n$ must be greater than the number of parameters to be estimated; the variable must be finite positive number; the regression model must be correctly specified (there is no specification bias or error in the model); and there is no perfect multicollinearity among the explanatory variables. Based on research variables, the model for the study can be specified as follows:

$$
\mathrm{L}=\alpha_{0}+\Psi_{1} \mathrm{X}_{1}+\Psi_{2} \mathrm{X}_{2}+\Psi_{3} \mathrm{X}_{3}+\Psi_{\mathrm{n}} \mathrm{X}_{\mathrm{n}}+\varepsilon
$$

Where L; represents the dependent variable which is a proxy of real gross domestic product (RGDP). Furthermore, $\mathrm{X}$; represents the explanatory variables, $\alpha$ is a slope parameter, which explains the status of the unobserved random variables in the absence of the explanatory variables. Similarly, $\Psi$ represents the coefficient parameter, which represents which explains the magnitude and direction of the linear relationships, and $\varepsilon$ represents the unobserved random variable or disturbance term. It captures the amount of variables which is unpredicted by intercepts and slopes parameters. In this study, the OLS model further suggests that real gross domestic product (RGDP) be the dependent variable or predictor variable and government expenditure, savings, foreign direct investment, investment, real interest rate and real exchange rate be the independent or explanatory variables. Thus, the OLS model is specified as follows:

$$
\mathrm{RGDP}=\alpha 0+\beta_{1} \mathrm{GEXP}+\beta_{2} \mathrm{SAV}+\beta_{3} \mathrm{FDI}+\beta_{4} \mathrm{INV}+\beta_{5} \mathrm{RINT}+\beta_{6} \mathrm{REXR}+\varepsilon
$$

Where: RGDP = real gross domestic product; GEXP = government expenditure; SAV = savings; FDI = foreign direct investment; INV = investment; RINT = real interest rate; $\operatorname{REXR}=$ real exchange rate; $\varepsilon=$ the error term; $\alpha_{0}=$ slope parameter and $\beta_{1}, \beta_{2}, \beta_{3}, \beta_{4}, \beta_{5}, \beta_{6}$, and $\beta_{7}$ represent the coefficients; which portrays the behaviour of (real gross domestic product, unemployment, inflation, household consumption, personal consumption expenditure, consumer price index, per capita income and savings). In the OLS model, the null hypothesis assumes that explanatory variables for real gross domestic product (RGDP) does not have an impact in the dependent variable. On the other hand, the alternative hypothesis is that the explanatory variables of RGDP have impact in the dependent variable. Thus, the hypothesis is stated as follows:

$\mathrm{H}_{0}: \beta_{1}=\beta_{2}=\beta_{3}=\beta_{4}=\beta_{5}=\beta_{6}$

$\mathrm{H}_{1}: \beta_{1} \neq \beta_{2} \neq \beta_{3} \neq \beta_{4} \neq \beta_{5} \neq \beta_{6}$

If the $\mathrm{P}$-value is greater than $5 \%$, then the study fail to reject the null hypothesis, implying that there is no impact of the explanatory variables on the dependent variable. On the other hand, if the P-value is less than $5 \%$, then the study rejects the null hypothesis, implying that there is impact of the explanatory variables on dependent variable.

\section{Empirical Findings and Discussions}

In this section, we present and discuss the estimated results using OLS technique. Firstly, we describethe data to examine the behavior. Since time series data are high frequency data, we subjected the variables to unit root test to check if all the variables in the estimated model are stationary or not. Augmented Dickey-Fuller (ADF) and Philips-Perron (PP) tests are employed. In addition, the assumptions of the OLS were observed and the results were estimated using NeweyWest Hac standard error to correct any form of unobserved shocks and autocorrelation.

\subsection{Descriptive Statistics}

The descriptive statistics is used to describe the basic features of data in a study. It gives the simple summary of the sample and the quantitative descriptions of the variables used in the study. From table 1 below, the minimum and maximum values are -1.584722 and 7.160592 respectively, which are the least value and the highest value of the coefficients. The probability values of the Jarque-Bera test are not statistically significant showing that there is evidence of serial correlation in the model. However, any form of 
serial correlation was believed to be corrected using Newey west Hac Procedure while estimating the model.

Table 1. Summary of Descriptive Statistics.

\begin{tabular}{|c|c|c|c|c|c|c|c|}
\hline & RGDP & GEXP & SAV & FDI & INV & RINT & REXR \\
\hline Mean & -0.298236 & 3.575972 & 4.321596 & -0.128034 & -0.436244 & -0.329808 & 0.810149 \\
\hline Median & 0.000000 & 4.508882 & 4.286380 & 0.294191 & 0.000000 & 0.000000 & 0.869963 \\
\hline Maximum & 0.532970 & 7.160592 & 6.944100 & 3.000000 & 0.567332 & 0.695976 & 1.753172 \\
\hline Minimum & -1.309359 & 0.102227 & 0.000000 & -1.340983 & -1.564509 & -1.584722 & 0.003139 \\
\hline Std. Dev. & 0.709108 & 2.793349 & 1.854494 & 1.036569 & 0.927852 & 0.959603 & 0.443301 \\
\hline Skewness & -0.074838 & -0.034726 & -0.213978 & 0.835958 & -0.184995 & -0.173818 & -0.147790 \\
\hline Kurtosis & 1.231200 & 1.240384 & 2.338423 & 4.145398 & 1.130066 & 1.193672 & 2.718419 \\
\hline Probability & 0.193752 & 0.198862 & 0.723721 & 0.117750 & 0.150699 & 0.171645 & 0.916861 \\
\hline Sum & -7.455899 & 89.39929 & 108.0399 & -3.200843 & -10.90609 & -8.245196 & 20.25372 \\
\hline Sum Sq. Dev. & 12.06803 & 187.2672 & 82.53952 & 25.78742 & 20.66181 & 22.10011 & 4.716389 \\
\hline Observations & 25 & 25 & 25 & 25 & 25 & 25 & 25 \\
\hline
\end{tabular}

Source: Author's Computation

\subsection{Unit Root Test}

This test is used to check for level of stationarity of the variables in the model in order to avoid spurious results. In the light of this, we employed the Augmented Dickey-Fuller (ADF) unit root test and Philips-Perron (PP) test. The reason why we complemented the two test was that, while ADF assumes that the error term is homoscedastic, the PhilpsPerron test make a no parametric correction of statistic when compared to Kwiatkowski-Phillips-Schmidt-Shin (KPSS) test. The assumption is that variables are either stationary at level i.e. $\mathrm{I}(0)$ or at first difference i.e. $\mathrm{I}(1)$ and not at second difference $\mathrm{I}(2)$ in order to avoid spurious result, because at
I(2) the result will be boosted. The decision rule is that we reject the null hypothesis "has a unit root" be rejected if the P-value if less than (0.05) 5\% level of significance, otherwise, do not reject. As shown in the table 2 below, the result of the unit root tests of both ADF and PP test shows that the null hypothesis has a unit root be rejected since all the p-values are statistically significance at 1\%. RGDP and GEXP was found to be integrated at order I(1) for both ADF and PP test and furthermore, SAV, FDI, INV, RINT and REXR was found to be integrated of order $\mathrm{I}(0)$ for both test. Having found this result, we move to envisage further if there is existence of the cointegration between the variables.

Table 2. Unit Root Results.

\begin{tabular}{|c|c|c|c|c|c|c|}
\hline \multirow{2}{*}{ Variables } & \multirow{2}{*}{ ADF } & \multicolumn{2}{|c|}{ Order of Integration } & \multirow{2}{*}{ PP } & \multicolumn{2}{|c|}{ Order of Integration } \\
\hline & & Level & $1^{\text {st }}$ Difference & & Level & $1^{\text {st }}$ Difference \\
\hline RGDP & $-6.990115 * * *$ & - & $\mathrm{I}(1)$ & $-13.51985^{* * *}$ & - & $\mathrm{I}(1)$ \\
\hline GEXP & $-4.785098 * * *$ & - & $\mathrm{I}(1)$ & $-4.787971 * * *$ & - & $\mathrm{I}(1)$ \\
\hline SAV & $-4.550851 * * *$ & $\mathrm{I}(0)$ & - & $-4.546366^{* * *}$ & $\mathrm{I}(0)$ & - \\
\hline FDI & $-3.038328 * * *$ & $\mathrm{I}(0)$ & - & $-4.374623 * * *$ & $\mathrm{I}(0)$ & - \\
\hline INV & $-6.270956 * * *$ & $\mathrm{I}(0)$ & - & $-6.104332 * * *$ & $\mathrm{I}(0)$ & - \\
\hline RINT & $-5.846379 * * *$ & $\mathrm{I}(0)$ & - & $-5.760994 * * *$ & $\mathrm{I}(0)$ & - \\
\hline
\end{tabular}

Source: Author's Conception

\subsection{Correlation Test}

Correlation test was carried out to examine the strength of relationship between the variables in the model. Also due to some unobserved shocks, spatial effects or autocorrelation, correlation test was performed and the outcome is presented in table 3 below.

Table 3. Correlation Matrix.

\begin{tabular}{|c|c|c|c|c|c|c|c|}
\hline & RGDP & GEXP & SAV & FDI & INV & RINT & REXR \\
\hline RGDP & 1 & & & & & & \\
\hline GEXP & -0.945181 & 1 & & & & & \\
\hline SAV & -0.8363130 & 0.909277 & 1 & & & & \\
\hline FDI & 0.708340 & -0.655165 & -0.621012 & 1 & & & \\
\hline INV & 0.878727 & -0.904940 & -0.8493867 & 0.519453 & 1 & & \\
\hline RINT & 0.882668 & -0.925995 & -0.873864 & 0.547346 & 0.991479 & 1 & \\
\hline REXR & 0.778144 & -0.252366 & -0.173032 & 0.151906 & 0.214585 & 0.231047 & 1 \\
\hline
\end{tabular}

Source: Author's computation

From table 3, it was observed that government expenditure (GEXP) and savings (SAV) depicted a high negative correlation to real gross domestic product (RGDP) and also, foreign direct investment (FDI), investment (INV), real 
interest rate (RINT), and real exchange rate (REXR) have strong positive correlation with real gross domestic product (RGDP). The negative outcomes of government expenditure (GEXP) and savings (SAV) to economic growth could be attributed to factor such as poor government effectiveness and political stability and absence of violence/terrorism in Nigeria which creates a fertile ground for corruption, looting, fraud, cybercrime, etc. at the detriment of the poor masses.

\subsection{Estimated Results}

In order to ascertain the impact of government expenditure, savings, foreign direct investment, on economic growth in Nigeria, the explanatory variables were regress on the dependent variables using ordinary least squares (OLS) method. Pre and post OLS estimation tests were carried to observe OLS assumptions and such tests include; Normality test, Breusch Godfrey Serial Correlation LM test, Whites Heteroscedasticity test and Ramsey RESET test, and there Pvalues are $0.00000,0.6819,0.1421$ and 0.0000 respectively. From the outcome of the results, it implies that the error term of the model is normally distributed and serially uncorrelated; the explanatory variables are homoscedastic and the model is well specified. In table 2 above, we noticed that almost all the variables are integrated of the same order, and for that reason we suspected that the variables move together in the long run. To ascertain if truly the variables cointegrated, we subjected the generated residual to unit root test at level form. Hence, the outcome shows the ADF stat (5.264244 ) to be greater than 5\% significant level, suggesting that the variables are cointegrated (see table 4 below).

Table 4. Residual Error Correction Result.

\begin{tabular}{llllll}
\hline & t-Statistic & $\mathbf{1 \%}$ level & $\mathbf{5 \%}$ level & $\mathbf{1 0 \% \text { level }}$ & Prob.* \\
\hline ADFtest statistic & -5.264244 & -3.752946 & -2.998064 & -2.638752 & 0.0003 \\
\hline
\end{tabular}

Source: Author's Computation

From the estimated result as presented in table 5 below, the coefficient of savings (SAV) influenced the real gross domestic product (RGDP) positively at 5\% level of significance and its estimated coefficient is 0.029826 . This suggests that a unit increase in the SAV may lead to about 0.029826 increases in the real gross domestic product
(RGDP). In addition, we observed foreign direct investment (FDI) impacted the RGDP positively and significantly at $1 \%$ critical level, with an estimated coefficient (0.175567). This show that units increase in FDI will lead 0.175567 increases in the gross domestic product.

Table 5. OLS Estimated Results.

\begin{tabular}{llll}
\hline Variable & Coefficient & Std. Error & t-statistic \\
\hline SAV & 0.029826 & 0.037474 & 6.795916 \\
FDI & 0.175567 & 0.052071 & 3.371709 \\
INV & 0.823263 & 0.390386 & 2.908842 \\
RINT & -0.871112 & 0.289957 & -3.004281 \\
REXR & -0.051669 & 0.083625 & -4.617865 \\
D(GEXP) & -0.203127 & 0.057258 & -3.547587 \\
ECM(-1) & -0.133296 & & 0.0034 \\
Constant & -0.012461 & & 0.0076 \\
R-Squared & 0.443046 & & 0.0023 \\
Adjusted R-Square & 0.288337 & & \\
Durbin-Watson Stat & 2.257062 & & \\
Normality Test & $27.81511(0.000001)$ & & \\
Serial Correlation Test & $0.392106(0.6819)$ & & \\
Ramsey Reset Test & $-0.523864(0.0000)$ & & \\
Heteroscedasticity Test & $2.838496(0.1421)$ & & \\
\hline
\end{tabular}

Source: Author's Computation. Department variable: D(RGDP)

In like manner, the results as shown in table 5 above revealed investment to be positive and significantly related to economic growth. Thus, suggesting that a unit increase in INV brings about 0.823263 increases in economic growth. Hence, real interest rate (RINT), real exchange rate (REXR) and government expenditure (GEXP) are negatively related to economic growth at $1 \%$ level of significance with $0.871112,-0.051669$ and -0.203127 coefficients respectively. This suggests that unit increase in RINT, REXR and GEXP brings about $-0.871112,-0.051669$ and -0.203127 decreases in the RGDP respectively. This finding supports evidence by $[50,2,3,7]$. In addition, thelag of error correction model has negative sign which further shows the speed of adjustment equilibrium. In addition, the result of the (ECM-1) is 0.133296 suggests that $13 \%$ of the long run is being accounted for in the short run. The measure of the goodness of fit, $\mathrm{R}^{2}(0.443046)$, shows that variations in the explanatory variables explain more than $44.3 \%$ of total variations in the RGDP in Nigeria. Thus, these findingswere found to be consistent with the studies of $[39,40,42]$.

\section{Conclusion and Policy Suggestions}

This study investigates the impact of government expenditure, savings, FDI on economic growth in Nigeria for 1995 to 2018. Using OLS estimator, the empirical evidence 
from the findings show that government expenditure, savings, FDI significantly impacted economic growth. Therefore, government expenditure, savings, foreign direct investments are key determinants of economic growth in Nigeria. Based on the findings, we suggestthat the Nigerian government should reduce the personal income tax so as to promote the disposal income and invariables savings. Also, effort should be made to promote stable and less volatile macroeconomic environment for the attraction of foreign direct investment inflow into Nigeria. This in turn could boost employment and increase in income and the individual savings. Further, we found government expenditure to negatively relate to economic growth. Hence, government spending in itself is not bad but should be utililize efficiently to help drive economic growth. Hence, we suggest that government spending should be reduced since it does not contribute immensely to the growth of the economy. However, the negative relationship could be as a result of the level of corruption in most of the developing countries. However, government may spend more on infrastructural development to encourage economic growth in Nigeria. Hence, good policy mix should be initiated to drive economic growth through reduction in both personal and company tax to boost savings, promotion of macroeconomic and legal environment to ensure the safety of lives and properties of investors and to promote the inflow of foreign investment and to reduce recurrent spending and pay more attention to infrastructural development.

\section{References}

[1] Acaravci A. and Ozturk, I. (2012), "Foreign direct investment, export and economic growth"; Empirical evidence from new EU Countries, Romanian Journal of Economic Forecasting, Vol. 2.

[2] Adeleke, K, et al (2014), "Impact of Foreign Direct Investment on Nigeria Economic Growth" International Journal of Academic Research in Business and Social Sciences, Vol. 4, No. 8.

[3] Adeniyi, O. et al (2015), "Financial development and economic growth in Nigeria:" Evidence from threshold modeling. Economic Analysis and Policy, Vol. 47.

[4] Adeolu, B. (2007), "FDI and Economic Growth: Evidence from Nigeria: The African Economic Research Consortium, City Square, Nairob, Kenya.

[5] Adil, M. et al (2017), "Wagner's Hypothesis"; An Empirical Verification, IIM Kozhikode, Society \& Management Review, Vol. 6, No. 1.

[6] Almfraji, A. and, Mohamoud, K. (2014), "Foreign direct investment and economic growth"; Procedia-Social and Behavioral Sciences, Vol. 109.

[7] Alzaidy, G. et al (2017), "The Impact of Foreign-direct Investment on Economic Growth in Malaysia" The Role of Financial Development, International Journal of Economics and Financial Issues, Vol. 7, No. 3.

[8] Anochiwa, L. et al (2018), "Foreign Direct Investment and
Economic Growth" Literature from 1980 to 2018, International Journal of Economics and Financial, Vol. 8, No. 5 .

[9] Awode, S. S and Akpa, E. O, (2018), "Testing Wagner's Law in Nigeria in the Short and Long Run"; Acta Universitatis Danubius Oeconomica, Vol. 14, No. 7.

[10] Ayinde et al., (2015), "Modeling Nigerian Government Expenditure, Revenue and Economic Growth" Co-integration, Error Correction Mechanism and Combined Estimators Analysis Approach. Asian Economic and Financial Review, Vol. 5, No. 6.

[11] Bayer, Y. and Ozturk, O. (2016), "Interaction between financial development and FDI inflows in Turkey: Paper Presented at Scientific Cooperation for the Future in the Social Sciences Usak Turkey.

[12] Begum, M. et al (2018), "Foreign direct investment-growth nexus revisited" New evidence from Bangladesh, International Journal of Economics and Financial Issues, Vol. 8, No. 3.

[13] Bolarinwa, S. T. and Obembe, O. B. (2017), "Empirical Analysis of the Nexus between Saving and Economic Growth in Selected African Countries" Journal of Development Policy and Practice, Vol. 2, No. 1.

[14] Bouchoucha, N. and Ali, W. (2019), "The impact of FDI on economic growth"; An estimate by the ARDL approach, Munich Personal RePEc Archive.

[15] Caesar, A. E. et al (2018), "Foreign direct investment, growth of output indicators and economic growth in China" Empirical evidence on causal links, International Journal of Economics and Financial Issues, Vol. 8, No. 3.

[16] Chowdhury, M. (2016), "Financial development, remittances and economic growth" Evidence using a dynamic panel estimation, Journal of Applied Economic Research, Vol. 10.

[17] Chude, N P. and Chude D I (2013), "Impact Of Government Expenditure On Economic Growth In Nigeria" International Journal of Business and Management Review, Vol. 1, No. 4, pp. 64-71, December 2013.

[18] Connolly, M. and Li, C. (2016), "Government spending and economic growth in the OECD countries" Journal of Economic Policy Reform, Vol. 19, No. 4.

[19] Danladi, J. D. et al (2015), "Government expenditure and its implications for economic growth: Evidence from Nigeria" Journal of Economics and Sustainable Development.

[20] De Mello, L. R. (1999)," Foreign direct investment -led growth" Evidence from times series and panel data. Oxford Economic Papers, Vol. 51.

[21] Faisal, F. et al (2016), "Impact of economic growth, foreign direct investment and financial development on stock prices in China" Empirical evidence from time series analysis, International Journal of Economics and Financial Issues, Vol. 6, No. 4.

[22] Getenet, G. (2017), "Trends and Determinants of Gross Domestic Saving in Ethiopia" Journal of Economics and Sustainable Development, Vo. 8, No. 5.

[23] Gupta, G. S. (1988), "Growth variations across developing countries": How much and why? Indian Economic Journal, Vol. 36, No. 3. 
[24] Hashm and Sedai (2016), "Domestic Savings and Economic Growth in India. I J A B E R, Vol. 14.

[25] Hassen, B. (2017), "Factors Affecting Savings as Means of Economic Growth" Ethiopian Journal of Economics, Vol. 26, No 2.

[26] Iheanacho, E. (2016), "The Contribution of Government Expenditure on Economic Growth of Nigeria Disaggregated Approach" International Journal of Economics \& Management Sciences, Vol. 5, No. 5.

[27] Jagadeesh, D. (2015), “The Impact of Savings on Economic Growth" An Empirical Study Based on Botswana. International Journal of Research in Business Studies and Management, Vol. 2, No. 19.

[28] Japheth, T, et al (2014), "Cointegration Analysis of Public Expenditure on Tertiary Education and Economic Growth in Nigeria" CBN Journal of Applied Statistics Vol. 5 No. 2.

[29] John, L and George, (2005), "Government Expenditure and Economic Growth" Evidence from Trivariate Causality Testing, Journal of Applied Economics, Vol. 8, No. 1.

[30] Lawrence, U. et al (2019), "Government Expenditure and Economic Growth: The Case of Nigeria, Proceedings of SOCIOINT, 6th International Conference on Education, Social Sciences and Humanities.

[31] Manh, V. (2005), "The Effects of FDI and Public Expenditure on Economic Growth: From Theoretical Model to Empirical Evidence, GSICS Working Paper Series.

[32] Mathias and Wilson (2019), Effect of Gross Domestic Savings on Economic Growth in Nigeria, International Journal of Economic, Commerce and Management, Vol. 7, No. 7.

[33] Najarzadeh, R. et al (2014), "Relationship between Savings and Economic Growth"; The Case for Iran. Journal of International Business and Economics, Vol. 2, No. 4.

[34] Norashida, O. et al 2018), "Impact of Government Spending on FDI Inflows" the case of AESAN-5, China and India; International Journal of Business and society, Vol. 19, No. 2.

[35] Nwaogu, U. G and Michael, J. R. (2015), "FDI, foreign AID, remittances and economic growth in developing countries" Review of Developing Economics, Vol. 19.

[36] Odionye, and Ugwuegbe, U. (2016), "Savings and Economic Growth Nexus: Evidence from Nigeria" Developing Country Studies, Vol. 6.

[37] Okere, P. et al (2019), "Government Expenditure and Economic Growth in Nigeria" International Journal of Economics and Financial Management, Vol. 4 No. 2.

[38] Olayungbo, D. and Olayemi, O. (2018), "Dynamic Relationship among Non-oil Revenue, Government Spending and Economic Growth in an Oil Producing Country" Evidence from Nigeria, Future Business Journal, Vol. 4.
[39] Panagiotis, P (2018), "The Effect of Government Debt and Other Determinants on Economic Growth" The Greek Experience, Journal of Economies, Vol. 6, No. 1.

[40] Pickson, R. et al (2017), "Savings Growth Nexus in Ghana:" Co integration and Causal Relationship Analyses. Theoretical Economics Letters, Vol. 7.

[41] Piotr, M. (2011), "The Relationship Between Savings and Economic Growth in Countries with Different Level of Economic Development, efinanse, Financial Internet Qurterly.

[42] Segun (2019), "The rising government expenditure in Nigeria"; Any influence on growth. Nigerian Institute of Social Economic Research.

[43] Serhan and Nermin (2010), "Are domestic savings and economic growth correlated?" Evidence from a sample of Central and East European countries, Problems and Perspectives in Management, Vol. 8, No. 3.

[44] Simionescu, M. (2016), "The Impact of BREXIT on the Foreign Direct Investment Economic Theories". Retrieved January 2018.

[45] Society \& Management Review, 6 (1).

[46] Soleimani, D. et al (2016), "Foreign direct investments and gross domestic product development in USA" International Journal of Economics and Financial Issues, Vol. 6, No. 3.

[47] Stephen, E. and Obah, D. (2017), "Impact of National Savings on Economic Growth in Nigeria (1990-2015)" International Journal of Economics and Business Management, Vol. 3, No. 4.

[48] Taban, S. (2010), "An Examination of the Government Spending and Economic Growth Nexus for Turkey Using Bound Test Approach" International Research Journal of Finance and Economics, Vol. 48.

[49] Vu Le, M. and Suruga, T. (2005), "Foreign Direct Investment, Public Expenditure and Economic Growth" The Empirical Evidence for the Period 1970-2001, Applied Economic Letters, Vol. 12.

[50] Wagner, A. (1893), "Grundlegung der Politischen Okonomie" 3rd ed., Leipzig, C. F. Winter.

[51] Yusuf S. et al (2015), "Analysis of Impact of Sectoral Government Expenditures on Economic Growth in Nigeria" Bound Test Cointegration Approach, European Journal of Business and Management, Vol. 7, No. 12.

[52] Zelalem, A. (2018), "Analysis of the Nexus between Gross Domestic Savings and Economic Growth in Ethiopia" Evidence from Toda-Yamamoto Causality Approach, International Journal of Current Research and Academic Review, Vol. 6, No. 9. 